九州大学学術情報リポジトリ

Kyushu University Institutional Repository

\title{
Variation of The Water Content of Leaves as Related to The Wilting of Plants
}

Koketsu, Ri ichiro

Botanical Laboratory, Kyushu Imperial University

https://doi.org/10.5109/22550

出版情報 : 九州大学大学院農学研究院紀要. 2 (3)，pp.93-116，1928-06. Kyushu Imperial University バージョン：

権利関係 : 


\author{
Journal of the Jepartment of Agriculture, Kyushu Inperial [inisersity, Vol 2, Nis. 3 . \\ June 1,1923

\section{VARIATION OF IHE WATER CONTENT OF IEAAVES AS RELATED TO 'THE WILTING OF PLANTS'}

\author{
Riichiro Kókersu
}

\title{
I. INTROULCIION
}

As it has been pointed out by several authors (14, 16, $17,7,19)$, the water content of the leaves of plants is not always constant, but shows a variation eluring the day, as is the case in regard to the foliar transpiring power (I I). Among them, Livingston and Brown (I4) paid much attention to the cliurnal change of foliar water content, as a factor regulating the transpiring power of leaves. When the rate of water supply does not cover the water loss from the tissue of leaves, the tissue should becone less moist and dry out nore or less. The first step of this internal drying of the tissue, which may be attained temporarily in a leaf at the time of maximum evaporation of a day, has been termed incipient drying by thesc authors. If such a drying process in a leaf tissue continues, the water content and corresponclently the turgor pressure of the tissue should decrease. Finally all turgiclity would be destroyed and a point, at which the wi'ting of a leaf is first externally to be seen, is now reached; and the more the water content of leaves decreases, the more the state of wilting proceeds. Therefore, any definite degree of wilting in a tissue would be correspond to a definte water deficit in the tissue, although experimental determination of such a definite 
relation between them might not be an easy task. In literature we can find few contributions dealing with this problem $(5,20)$. Among others Caldwell (5) discovered, that a plant has a definite amount of water in the leaves when wilting begins and at the time of so-called permanent wilting. But our knowledge of this relation is at present quite insufficient. The writer worked, therefore, during 1919-1920, when he was studying on the water relation of wilting plants in the Plant Physiological Laboratory of the Johns Iopkins University Baltimore, on the problem in question, with some reasonable results. But unavoidable circumstances compeiled him to leave these results unpublished up to the present. Recently the writer was able to continue the work on this problem somewhat further in the Botanical Laboratory of Fukuoka The present paper is based on the results obtained in those two laboratorics.

It is the writer's pleasant obligation to express his gratitude to Professor B. F. Livingston of the Johns Hopkins University for his helpful suggestions in this work and his great kindness in permitting the writer to use the facilities and equipment of his laboratory.

\section{MATERIAL ANI) METIIOD}

The plant materials used in this work were Coleus Blumei, Glycine Soja and Mimosa pudica They were planted in pots. When it was desired to wilt them, they were placed on a table without further watering. For determining the water content of leaves, the common method of weighing, drying and reweighing was employed. As the leaves were plucked, they were placed inmediatcly in tarred glass tubes and tightly stoppered. After being weighed, the open tubes were placed in a drying oven of temperature $100-103^{\circ} \mathrm{C}$, and the final dry weight obtained by reweighing the re-stoppered tubes without removing or handling the leaves, but after cooling in a desiccator.

For the cultivation of plants, several kinds of soil or their mixtures, with different water holding capacity were used, the water capacity having been determined by the method of IIn.GARD (6). Sand, loam, humus and mixtures were principally used for the work in Baltiniore and were numbered according to the value of the water holding capacity, which was given in percentage on the basis of the oven-dry volume (Tab. I). 
Tab. I. The water holding eapacity of soils used in experinents at Baltimore.

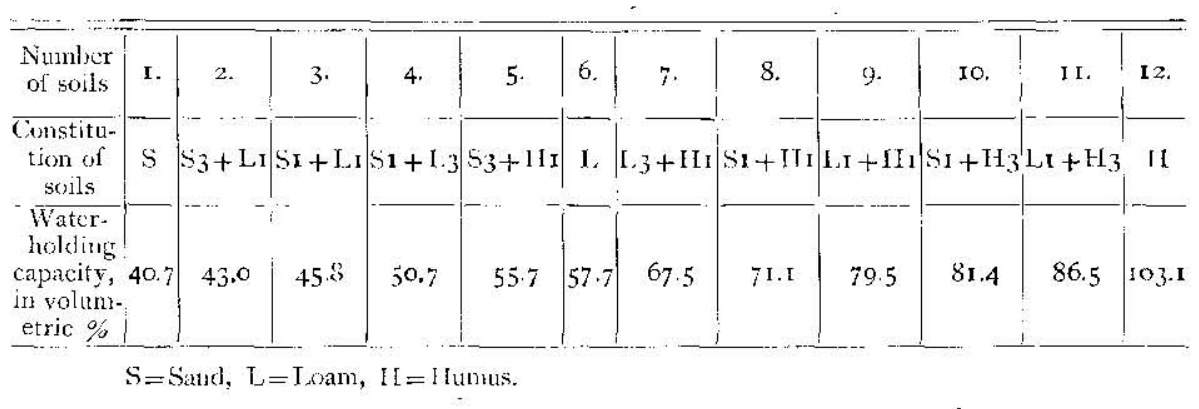

For the experiments carried out in our laboratory at Fukuoka other kinus of soil were used. The water holding capacity of these soils was however not directry determined. These soils were numbered a, b, c and $d$, according to the value of the water resiclue in soils at the critical wilting point of Mimosa putica cultured in each soil, instead of the water holding capacity (Tab. 2).

Talb. 2. The water content: of soils at the critical pentut of willing of Ahmesa pedica rooted therein (Soils used at liukuokaj.

\begin{tabular}{|c|c|c|c|c|c|c|c|}
\hline \multicolumn{4}{|c|}{ Number of soils } & \multicolumn{2}{|l|}{ a } & \multirow{2}{*}{$\begin{array}{l}\mathrm{c} \\
\text { Mixture of } \\
\text { sand and } \\
\text { bumous soil }\end{array}$} & \multirow{2}{*}{$\frac{d}{\begin{array}{c}\text { [ tumests } \\
\text { soil }\end{array}}$} \\
\hline Kinds of soil & $\cdots$ & $\cdots$ & $\cdots$ & $\begin{array}{l}\text { Sandy } \\
\text { garden-soil }\end{array}$ & $\begin{array}{l}\text { Ordinary } \\
\text { garden-soil }\end{array}$ & & \\
\hline $\begin{array}{l}\text { Critical water } \\
\text { of owen-dry }\end{array}$ & $\begin{array}{l}\text { tent } \\
\text { ume }\end{array}$ & $\begin{array}{l}\text { iven in } \\
\text { soil }\end{array}$ & $\%$ & 5.49 & 8.95 & 9.64 & 20.33 \\
\hline
\end{tabular}

As the index of the water content of leaves, its percentage on the basis of ftesh weight or dry weight was ariopted in many cases in the literature. But the fiesh or diry weight of leaves is of a variable nature, especially in our case, where the plant materials vere studied in the progressive phases of wilting. The writer preferred, therefore, to use the amount of water contained in the unit area of leaves as the better index for our purpose, although some sampling error, which may be caused by the difference of the thickness of icaves, must be expected. The area of the leaf was measured by means of a planimeter. The percentage content of water based on the fresh and dry weight was also taken into consideration for comparing their applicability. In the parts 
of experiment, which were carried out in the laboratory at Fukuoka, the so-called powder method for determining the water content $(8,10$, I3) was also employed.

\section{EXPERIMEN'S}

I. Coleus.-A variegated yellow purple and a purple variety

Four equally grown plants of variegated variety, which were cultivated in pots in common garden soil, were well watered in the lay of beginning the experiment. One of them was tested for the water content of its leaves on the day of watering, while the others were allowed to wilt. Among them one was studied for the same purpose, when it began to wilt slightly, another plant, when it reached the ciay of the so-called permanent wilting in the sense of Bkiggs and ShANTZ $(2,3,4,21)$, and the last one, when it bccane excessively wilted. Another series of experiment was made with the purple variety.

Determinations of the foliar water content of each plant were always tried at the hours 13:30 and 23:30. Five mature leaves on one side of the leaf pairs were collected for the day-time determination, and the five opposite leaves were removed for the night-test. The values found and the ratios between the day and night values are given in the table 3 .

Taking the water content per unit area $\left(1 \mathrm{~cm}^{2}\right)$ into account, we see, that the water content of leaves becones smaller and smaller as the wilting progresses. The values of the water content given by the percentage on the basis of the dry or fresh weight slowed neverthless some points of non-uniformity, though there was, roughly speaking, the same tenciency in the relation in question. The reason, why such a lack of uniformity appears, must be lue to the circumstance, that the variations of the dry and fresh weight of plant materials used are wholly neglected in these cases. In the case where the foliar water content of the variegated variety was given in the percentage on the basis of the dry weight, the values for the slightly wilted material came nuch larger than those for the healthy material. This must be namely an index error probably caused by the negligence of the diminution of dry matter in the wilted material.

As regards the relation between the day and night values of the water content, there was a different tendency as the plant material used was differcnt. As for the variegated variety, the night values were 
Tah. 3. Water content of the leaves of (iltus, cultivated in common garden soil at the four different stages of wilting healthy (I), slightly willed (II), permanently wilted (III\} and excessively wilted (IV)

\begin{tabular}{|c|c|c|c|c|c|c|c|c|c|}
\hline \multirow[b]{2}{*}{ Stages of wilting } & \multicolumn{3}{|c|}{ Per $1 \mathrm{~cm}^{2}$ area in $\mathrm{mg}$. } & \multicolumn{3}{|c|}{$\%$ on dry weight } & \multicolumn{3}{|c|}{$\%$ on fresh wcight } \\
\hline & $\begin{array}{l}\text { Hay value } \\
\text { (1) }\end{array}$ & $\begin{array}{l}\text { Xight value } \\
\text { (II) }\end{array}$ & $\begin{array}{l}\text { Day-night } \\
\text { ratio (I/II) }\end{array}$ & $\begin{array}{l}\text { Day value } \\
\text { (I) }\end{array}$ & $\begin{array}{l}\text { Night value } \\
\text { (II) }\end{array}$ & $\begin{array}{l}\text { Day-night } \\
\text { ratio (I/II) }\end{array}$ & $\begin{array}{c}\text { Day value } \\
\text { (J) }\end{array}$ & $\begin{array}{l}\text { Night value } \\
\text { (II) }\end{array}$ & $\begin{array}{l}\text { Day-night } \\
\text { ratio (I/II) }\end{array}$ \\
\hline \multicolumn{10}{|l|}{ Variegated variety } \\
\hline I & $\times 9.18 \%$ & 20,00 & 0.96 & 1320 & 1596 & $0 . s_{3}$ & 93.0 & 94.0 & 0.99 \\
\hline II & 18.34 & 18.78 & 0.98 & 1547 & 1737 & 0.80 & 93.8 & 94.4 & 0.99 \\
\hline III & $17.41 \%$ & 17.48 & 1.00 & 1409 & 1504 & 0.94 & 93.4 & 93.8 & 1.00 \\
\hline IV & 16.58 & 17.10 & 0.97 & 1053 & 1246 & 0.85 & $9 \mathbf{L} \cdot 3$ & 92.5 & 0.99 \\
\hline \multicolumn{10}{|l|}{ Purple variety } \\
\hline I & $19.49^{*}$ & 19.3 .3 & 1.01 & 1588 & $\mathbf{1 3 3 5}$ & 1.59 & 94.2 & 93.5 & $r .0 I$ \\
\hline II ' & 18.07 & 18.82 & 0.96 & 1350 & 1220 & $I . I T$ & 93.1 & 92.5 & 1.01 \\
\hline III & $17.15^{*}$ & 16.95 & $1.0 I$ & II 33 & 1051 & 1.08 & 91.9 & 91.3 & $1.0 r$ \\
\hline IV & 14.87 & 14.44 & 1.03 & 916 & 885 & 1.04 & 90.3 & 90.0 & 1.00 \\
\hline
\end{tabular}

*The ratio of the water content at the point of permanent wilting to that at the state of full turgidity: $17.41 / 19.18=0.91$, 17. $15 / 19.49=\mathbf{0 . 8 8}$. 
larger than that of the day in all stages of wilting, while in the case with purple variety the relation appeared conversely. The reason, why such a different relation occured in this case, might be attributed to the difference of properties on the plants themselves, or to the difference of the environmental circumstances. To tcll the trutl, the atmospheric condition of the days, during which the experiments with the variegated variety were carried out, was much drycr than that of the days with another variety. It was supposed that the water content of leaves might fall into the lower values at the arid period of the clay or at the daytime, as it was suggestud by I.lvingsron and Brown (14). This was at least one of the reason, why the day value for the variegated variety came to light somewhat lower than the night value. In connection with this relation it was worthy of remark, that the day-night ratio of the water content became nearer to unity as the wilting procceded, until the plant fell into the state of permanent wilting. That is to say, the degree of diurnal fluctuation of foliar water content reaches its minimum at this point. On the contray the purple variety, which was experimented on during rather wet days, showed no such tendency, namely, that the value of the foliar water content in the day time should become lower than that of the night value of the sane 24 hour period. This plant scemed therefore simply to lose its leaf moisture decrasingly during the process of wilting without visible fluctuation.

By comparing the results obtained in both series of experiment, there is a remarkable fact brought to light, natuely, that the water content of leaves at the tine of full turgidity, of slight witting and of the permanent wilting secms to be approximately alike, or probably constant in each stage, though the values shown in the percentage on the basis of the dry weight are found to correspond less accurately. This might be caused by the probable fact, that the content of the dry matter or its variation in those two materials does not agree to each other (Tab 3). It is suggested therefore by this experiment, that the leaves of Coleus contain a constant amount of water corresponding to any definite stage of wilting.

\section{Glycine.-A variety named Wilson}

In this series of experiments soy bean plants seven or eight weeks old, which were cultivated in five different soils, were used: sand, sandloam mixture, loam, sand-humus mixture and humus. In each pot, there 
were six plants; and each plant bore one pair of simple leaves and two or three well grown compound leaves. The water content of the leaves was determined on the day of full turgidity, at the beginning of wilting and at the time of permanent wilting. The collection of leaves foj each determination was made between the hours I I and 16 , when the leaves were in the required critical state of wilting; one middle leaflet and two side leaflets in the first compound leaves being picked at each time of determination from different plants in each pot.

The results of this experiment are shown in the table 4, where the observed values for each plant as well as the relative values compared with the average value are given. The values found by the area or dry weight method of indication showed, that the foliar water content of material used decreased renarkably as the plants wilted, although it was less remarkable in the case of the fresh weight method. The latter result is of course not so reliable to the material, because the method of inclication used is not fitted.

According to the results found by the area method, which must be the most reasonable method for our purpose in this case, the foliar water content seems to becone larger, as the water holding capacity of the soil used grows larger. This is noticeable in the leaves in any stage of wilting, but most clearly in those at the time of permanent wilting. This fact is not so clearly indicateci by the values found by the fresh or dry weight method, which must involve in themselves methudical error in this case ( $\sec 8,10,13,19$ ). This difference of the foliar water content, caused by the difference of culture soils indicates presumably, that the water retaining power of the cells in the leaf of plants, which were cultivated in the soil of higher water holding capacity, may be larger than that of the plants cultivated in the soil of lower water holding power or in the soil with higher amount of available water ${ }^{2}$.

On the other hand the ratis between the foliar water content at the time of the permanent wilting and at the time of full turgidity appeared to be the larger, the larger was the water holding capacity of the culture soils. This seems to indicate, that the resistance of the leaf tissues against the water clesiccating power becomes higher in the plants cultivated in the soils with higher water lolding capacity.

2 It must be kept in mind, that the plants used in this experiment were all cultivatcd in soils watered every day. Thus the plants, which were cultivated even in the soils of lower water holding capacity, never suffered from the lack of available waler in the soil. 
Tab. 4. Water content of the leaves of Giycine, cultivated in five different soils, at the time of full turgidity (I), at the beginning of wilting (II) and at the time of permanent wilting (III).

\begin{tabular}{|c|c|c|c|c|c|c|c|c|c|c|c|c|}
\hline \multirow{2}{*}{$\begin{array}{l}\text { Nimber of } \\
\text { culture soils }\end{array}$} & \multicolumn{4}{|c|}{$\begin{array}{c}\text { Per I } \operatorname{con}^{2} \text { arca in mg. at the } \\
\text { stage of }\end{array}$} & \multicolumn{4}{|c|}{$\begin{array}{l}\% \text { on dry weight at the } \\
\text { stage of }\end{array}$} & \multicolumn{4}{|c|}{$\begin{array}{c}\% \text { on fresh weight at the } \\
\text { stage of }\end{array}$} \\
\hline & I & II & III & III/I & I & II & III & $\mathrm{III} / \mathrm{I}$ & I & II & III & III/I \\
\hline Observed values & & & & & & & & & & & & \\
\hline $\mathbf{I}$ & 10.03 & $9.1 \mathrm{I}$ & 5.65 & 0.56 & 451 & 309 & 262 & $0.5^{8}$ & 81.8 & 75.5 & 72.4 & 0.89 \\
\hline 3 & 11.70 & 10.22 & $6 . c 0$ & 0.51 & 588 & 404 & 300 & 0.51 & 85.5 & 80.2 & 75.0 & 0.88 \\
\hline 6 & 11.14 & 10.25 & 6.28 & 0,56 & $43^{2}$ & 379 & 285 & 0.66 & 81.2 & 79.1 & 74.0 & 0.91 \\
\hline$\Leftrightarrow$ & 13.49 & 12.95 & 9.40 & 0.70 & 499 & 406 & 419 & 0.8 .4 & $83 \cdot 3$ & $8 \mathrm{r} .2$ & 80.7 & 0.97 \\
\hline 12 & 14.16 & 13.05 & 10.54 & 0.7 .7 & 487 & $4 \sqrt{66}$ & $45 \mathrm{I}$ & 0.43 & 83.1 & 82.3 & 81.8 & 0.98 \\
\hline Average & $x 2.10$ & II.I 2 & 7.57 & 0.61 & $49 \mathrm{I}$ & 393 & 34.3 & 0.70 & 83.0 & 79.7 & 76.8 & 0.93 \\
\hline Relative values & & & & & & & & & & & & \\
\hline I & 83 & $\$ 2$ & 75 & - & 92 & 79 & 76 & - & 99 & 95 & 94 & - \\
\hline 3 & 97 & 92 & 79 & - & 120 & 103 & 87 & - & 103 & 10r & 98 & - \\
\hline 6 & 92 & 92 & 83 & - & 88 & 96 & 83 & - & 98 & 99 & 96 & - \\
\hline 8 & III & I 16 & 124 & - & 102 & 103 & 122 & - & 100 & 102 & 105 & - \\
\hline 12 & 117 & 117 & 1.39 & - & 99 & 119 & I $3 \mathbf{I}$ & - & 100 & 103 & 107 & - \\
\hline Average & 100 & 100 & 100 & - & 100 & 100 & 100 & - & 100 & 100 & 100 & - \\
\hline Deviation $\left( \pm \frac{\Sigma \Delta}{n}\right)$ & \pm 11.2 & \pm 13.4 & \pm 25.2 & - & \pm 8.6 & \pm 10.0 & \pm 21.4 & - & $\pm \mathrm{I} .2$ & \pm 2.4 & \pm 4.8 & - \\
\hline
\end{tabular}




\section{Coleus.-A pale yellow variety}

Twelve plants, which belong to one and the same variety, were cultivated in twelve different kinds of soil. In these materials the foliar water content was determined at the stage of permanent wilting only. The purpose of this experiment was to study the influence of the moisture conclition in the culture soils upon the critical water content of leaves.

At the hour $16: 30$ on the day of permanent wilting, three middle aged leaves were collected for the day-time test, and the three opposite leaves at the hour 23:30 of the same ciay for the night-time study. 'The day-night ratio of the foliar water content found in each plant was in almost all cases very near to unity. The ratios between the average value of the day and the night, which were calculated for the water content per unit area and for the percentage on the basis of the fresh weight was 1.003 and 1.000 respectively, while the ratio obtained by the ciry weight method was 0.943 . The variation of the values found at these two test times was, that is to say, but a little for each case, as it was expected. Therefore the average results of each two tests for each plant was adopted as the index for the critical water content in question (Tab. 5).

The index based on the area method being taken into consideration, it was found, that the amount of water hold in the leaves of each plant was very ncar to that in every other: the maximum and minimum vilue were namely $17.73 \mathrm{mg}$. and $14.05 \mathrm{mg}$. respectively for $1 \mathrm{~cm}^{2}$ ared, the average value being $15.99 \mathrm{mg}$. In other worcls, the mean deviation of the relative values for the average, which was calculated after the formula $\pm \frac{2 J}{n}$, was only $4.2 \%$. However, there was a tendency to be scen, even if very slightly, that the water content of the plants cultivated in the seils with higher water holling capacity is somewhat smaller than that found in other plants.

This relation could be found also in the results obtained by the fresh weight method. But accorcling to the results based on the determination by the dry weight method, the difference of the foliar water content of plants cultivated in different kinds of soil came to light more remarisably. But the letter result is, presumably, only a mere show caused by the methodical error, because the foliar dry matter content of plants, which were cultivated under different soil conditions, would show not a little variation. 
Tab. 5. Water content of the leaves of Colets, cultivated in twelve different kinds of soil, on the day of permanent wilting.

\begin{tabular}{|c|c|c|c|c|c|c|}
\hline \multirow{2}{*}{$\begin{array}{l}\text { Number of } \\
\text { culture soils }\end{array}$} & \multicolumn{2}{|c|}{ Per $1 \mathrm{~cm}^{2}$ area in $1 \mathrm{ng}^{\mathrm{s}}$} & \multicolumn{2}{|c|}{$\%$ on dry weight } & \multicolumn{2}{|c|}{$\%$ on fresh weight } \\
\hline & $\begin{array}{l}\text { Observed } \\
\text { values }\end{array}$ & $\begin{array}{l}\text { Relative } \\
\text { values }\end{array}$ & $\begin{array}{l}\text { Ohserved } \\
\text { values }\end{array}$ & $\begin{array}{c}\text { Relative } \\
\text { values }\end{array}$ & $\begin{array}{l}\text { Olsscrved } \\
\text { vahues }\end{array}$ & $\begin{array}{l}\text { Relative } \\
\text { values }\end{array}$ \\
\hline I & 16.21 & IOI & 1740 & 145 & 94.3 & $\mathrm{ro2}$ \\
\hline 2 & 17.73 & 111 & $\mathbf{I} 299$ & 108 & 92.9 & IOI \\
\hline 3 & 16.85 & 105 & 1280 & 107 & 92.8 & Iol \\
\hline 4 & 16.40 & 103 & 1157 & $\mathrm{~s} 6$ & 92.1 & 100 \\
\hline 5 & 16.02 & 100 & I 123 & 94 & 91.4 & 99 \\
\hline 6 & 15.86 & 99 & 1265 & 106 & 92.4 & 100 \\
\hline 7 & 5.88 & $\$ 9$ & 1049 & 87 & 92.5 & 100 \\
\hline 8 & 16.68 & 104 & I.395 & 116 & 93.2 & 101 \\
\hline 9 & 15.42 & 96 & 995 & 8.3 & 92.0 & 100 \\
\hline 10 & $14.7^{2}$ & 92 & 1088 & OI & 91.7 & 99 \\
\hline I I & 16.06 & 100 & 1098 & 92 & 91.7 & 99 \\
\hline 12 & 14.05 & 88 & $80_{4}$ & 75 & 90.0 & 98 \\
\hline Average & 15.99 & 100 & 1199 & 100 & 92.3 & 100 \\
\hline $\operatorname{Dcviation}\left( \pm \frac{2 \Delta}{n}\right)$ & - & \pm 4.2 & - & \pm 13.7 & - & \pm 0.8 \\
\hline
\end{tabular}

Obscrved values are given in the average of day- and night-valuc.

\section{Glycine -A variety named Wilson}

In this series of experiments, the water content of the first ordinary simple leaves of the soy bean plants eight weeks old, which were cultivated in five different soils, as in the case of the experinent 2., w.1s determined. The determinations were made at the time of full turgidity and of permanent wilting, four leaves bing collected for each detcrmination from different individuals in the same pot.

The results obtained by this experiment coincided with those of the experiment 2. (Tab. 6). The difference of the foliar water content of plants cultivated in different kincis of soil again appeared more remarkable in the stage of permanent wilting than in the stage of full turgiclity. The ratio between the values of water content at these two stages 
Tab. 6. Water content of the first ordinary simple leaves of devine, cultivated in five different linds of soil, at the time of full turgidity and of permanent wilting.

\begin{tabular}{|c|c|c|c|c|c|c|c|c|c|}
\hline \multirow{2}{*}{$\begin{array}{l}\text { Number of } \\
\text { culture soils }\end{array}$} & \multicolumn{3}{|c|}{ Per $1 \mathrm{~cm}^{2}$ area in mg. at the time of } & \multicolumn{3}{|c|}{$\%$ on dry weight at the stage of } & \multicolumn{3}{|c|}{$\%$ on fresh weight at the stage of } \\
\hline & $\begin{array}{c}\text { full } \\
\text { turyidity }\end{array}$ & $\begin{array}{l}\text { pernanent } \\
\text { wilting }\end{array}$ & Ratio & $\begin{array}{l}\text { full } \\
\text { turgidity }\end{array}$ & $\begin{array}{l}\text { permanent } \\
\text { wilting }\end{array}$ & Ratio & $\begin{array}{l}\text { full } \\
\text { turgidity }\end{array}$ & $\begin{array}{l}\text { permanent } \\
\text { wilting }\end{array}$ & Ratio \\
\hline Observed valucs & & & & & & & & & \\
\hline I & 9.02 & $4.5^{6}$ & $0.5 x$ & 439 & 197 & 0.45 & $8 \mathbf{r} .5$ & 66.3 & $0.8 x$ \\
\hline 3 & 10.21 & 5.96 & 0.58 & 428 & 245 & 0.57 & $8 \pi \cdot 1$ & 71.0 & 0.88 \\
\hline 6 & 10.44 & 5.34 & 0.51 & 459 & 238 & 0.52 & 82.2 & 70.4 & 0.86 \\
\hline 8 & $\mathbf{1 2 . 7 9}$ & 7.96 & 0.62 & 534 & 344 & 0.67 & 84.3 & 77.5 & 0.92 \\
\hline 12 & 13.16 & 9.55 & 0.73 & 512 & 339 & 0.66 & 83.7 & $77 \cdot 3$ & 0.92 \\
\hline Average & 11.12 & 6.67 & 0.59 & 474 & 273 & 0.57 & 82.6 & 72.5 & 0.88 \\
\hline Relative values & & & & & & & & & \\
\hline I & $8 \pi$ & 68 & - & 93 & 72 & - & 99 & 91 & - \\
\hline 3 & 92 & 89 & - & 90 & 90 & - & 98 & 98 & - \\
\hline 6 & 94 & 80 & - & 97 & 87 & - & 100 & 97 & - \\
\hline 8 & II 5 & 119 & - & 113 & I 26 & - & 102 & 107 & - \\
\hline 12 & II 8 & 143 & - & 108 & 124 & - & IOI & 107 & - \\
\hline Average & 100 & 100 & - & 100 & 100 & - & 10o & 100 & - \\
\hline Deviation $\left( \pm \frac{y \Delta}{n}\right)$ & \pm 13.2 & \pm 25.0 & - & \pm 8.2 & \pm 20.2 & - & $\pm \mathrm{I} .2$ & \pm 5.6 & - \\
\hline
\end{tabular}


studied was also found to be larger in the plants cultivated in the soils with ligher water holding capacity. In this connection, there was a remarkable fact to be seen in the two series of experiment 2 . and 4 , namely, that the ratio in question, uncer the results obtained by the area method, was found to be similar in those plants cultivated in the Same kind of soil, the average value for cach series of experiment being $0.6 \mathrm{I}$ and 0.59 respectively (Tab. 7). It seems therefore, that the relation of the water content of a given plant at the stage of permanent wilting to the normal water content of the same plant is likely to be the same for a given conclition of suils.

Tab. 7. Comparison of the ratios of the values for the water content of the leaves of Gitycine at the point of permanent wilting to that at the state of full turgidity found by two series of experiment (F.xp. 2. and Exp. 4.), determmations being made by the area method.

\begin{tabular}{|c|c|c|c|c|c|c|c|}
\hline \multirow{2}{*}{$\begin{array}{l}\text { Number of } \\
\text { culture soils }\end{array}$} & \multicolumn{2}{|c|}{ Experiment 2.} & \multicolumn{2}{|c|}{ Experiment 4.} & \multicolumn{2}{|c|}{ Average } & \multirow{2}{*}{$\begin{array}{l}\text { Jeviation } \\
\text { of valucs } \\
\text { in } \%\end{array}$} \\
\hline & $\begin{array}{l}\text { Observed } \\
\text { values }\end{array}$ & $\begin{array}{l}\text { Relative } \\
\text { values }\end{array}$ & $\begin{array}{l}\text { Ohserved } \\
\text { values }\end{array}$ & $\begin{array}{l}\text { Relative } \\
\text { values }\end{array}$ & $\begin{array}{c}\text { Observed } \\
\text { values }\end{array}$ & $\begin{array}{l}\text { Relative } \\
\text { values }\end{array}$ & \\
\hline 1 & 0.56 & 105 & 0.51 & 95 & 0.5 .35 & 100 & $\pm j$ \\
\hline 3 & $0.5 \mathbf{I}$ & 94 & 0.58 & 106 & 0.545 & 100 & \pm 6 \\
\hline 6 & 0.56 & 105 & 0.51 & 95 & 0.535 & 100 & \pm 5 \\
\hline 8 & 0.70 & 106 & 0.62 & 94 & 0.660 & 100 & \pm 6 \\
\hline 12 & 0.74 & IoI & 0.73 & 99 & 0.735 & 100 & \pm 1 \\
\hline Average & 0.61 & $\mathrm{IC2}$ & 0.59 & 98 & 0.600 & 100 & \pm 2 \\
\hline
\end{tabular}

5. Colezs.-Another variety with variegated leaves

In this case another variegated varicty of Coleus, which was cultivated in four different soils (soil $a, b, c$ and d), was used for experiment, two series of experiment being carried out. The water content of leaves was determined at the stage of permanent wilting in comparison with the content at the stage of full turgidity, and the results calculated for I $\mathrm{cm}^{2}$ leaf arca as well as for the percentage on the basis of the dry weight, were taken into consideration (Tab. 8). But the results obtained by the dry weight method seemed clearly to be unreasonable, because the water content at the stage of permanent wilting came to light sometimes as if it was larger than that at the stage of full turgidity. 
Tab. 8. Water content of the leaves of Coleus, cultivated in four different soils, ait the time of full turgidity and of permanent wilting.

\begin{tabular}{|c|c|c|c|c|c|c|c|}
\hline \multirow{2}{*}{$\begin{array}{c}\text { Number of culture } \\
\text { soils }\end{array}$} & \multicolumn{3}{|c|}{ Values at full turgidity } & \multicolumn{3}{|c|}{ VaIues at permanent willing } & \multirow{2}{*}{$\begin{array}{l}\text { Ratio } \\
\text { II } / 1\end{array}$} \\
\hline & $\begin{array}{l}\text { First } \\
\text { exp. }\end{array}$ & $\begin{array}{l}\text { Siecond } \\
\text { exp. }\end{array}$ & $\begin{array}{c}\text { Averags } \\
\text { (I) }\end{array}$ & $\begin{array}{c}\text { First } \\
\text { exp. }\end{array}$ & $\begin{array}{l}\text { Second } \\
\text { exp. }\end{array}$ & \begin{tabular}{|c|} 
Average \\
(II)
\end{tabular} & \\
\hline \multicolumn{8}{|l|}{ Per $1 \mathrm{~cm}^{2}$ area in $\mathrm{mg}$} \\
\hline a & $23 \cdot 1$ & $2: .7$ & 22.4 & $2 \mathrm{I} .2$ & 20.8 & 21.0 & 0.94 \\
\hline b) & 22.9 & 22.7 & 22.8 & 20.8 & 20.0 & 20.4 & 0.80 \\
\hline c & 21,6 & $\because 2.1$ & 21.9 & I 9.6 & I9.2 2 & 19.4 & 0.89 \\
\hline d & 23.8 & 20.2 & 22.0 & 21.5 & $I_{7} .0$ & 19.7 & $0 ., 00$ \\
\hline Average & 22.9 & 21.7 & 223 & 20.8 & I9. 5 & 20.1 & 0.91 \\
\hline \multicolumn{8}{|l|}{$\%$ on dry weight } \\
\hline a & I 3.55 & I $2 \%$ & 1322 & I 194 & I 294 & 1244 & 0.94 \\
\hline 1) & 1196 & 1155 & 1176 & II2] & 1021 & $107 \mathrm{I}$ & $0.0 I$ \\
\hline$c$ & 1303 & 1406 & 1355 & 1129 & 1612 & 1371 & I.OI \\
\hline $\mathrm{d}$ & $\mathbf{I}_{3} \mathbf{I}^{2}$ & 966 & 1142 & 1162 & 1031 & 1097 & 0.06 \\
\hline Average & 1293 & 1204 & 1249 & 1152 & 1240 & 1196 & 0.96 \\
\hline
\end{tabular}

According to the results obtained by the area method, there were no unreasonable data to be found, and the results of the two series of expcriment were alike in general. The difference of the water content of leaves as related to the difference of the culture soil was however scarcely recognizable, though there was some tendency toward the value of the water content in the soils with higher water holding capacity appearing somewhat smaller than that of other soils. This will be probably caused by the matter of fact, that there was small variation in the water relation of the soils used for this experiment.

The ratio between the value at the stage of permanent wilting and that of the stage of full turgiclity, being calculated for cach plant by the average value of the two series of experiment, was $0.89-0.94$, the average value of all materials used being $09 \mathbf{I}$. This value agreed well with the value obtained by the experiment $I$. In other words this ratio seems to be a definite value for the Coleus plants.

\section{Glysine.-Another variety}

The soy bcan plants used in this experiment were well grown to 
the maturity of flowering. Three kinds of soil (Soil a, b and d) were used for cultivation. The determination of water content was carried out at the stage of full turgidity and the stage of permanent wilting, the results of determinations being given in the values per unit area of the leaf, the values in percentage on the basis of the dry weight and the values per $1 \mathrm{~cm}^{3}$ powder obtained from the le if tissue $(8,10)$.

Tab. 9. Water content of the leaves of Glycime, cultivated in three differcnt kinds of soil, at the time of full turgidity and of permanent wilting.

\begin{tabular}{|c|c|c|c|c|c|c|c|}
\hline \multirow{2}{*}{$\begin{array}{l}\text { Number of culture } \\
\text { soils }\end{array}$} & \multicolumn{3}{|c|}{ Values at full turgidity } & \multicolumn{3}{|c|}{ Values at permanent wilting } & \multirow{2}{*}{$\begin{array}{l}\text { Ratio } \\
11 / 1\end{array}$} \\
\hline & $\begin{array}{l}\text { First } \\
\text { exp. }\end{array}$ & $\begin{array}{l}\text { Second } \\
\text { exp. }\end{array}$ & $\begin{array}{l}\text { Average } \\
\text { (i) }\end{array}$ & $\begin{array}{l}\text { First } \\
\text { exp. }\end{array}$ & $\begin{array}{l}\text { Secund } \\
\text { exp. }\end{array}$ & $\begin{array}{l}\text { Averase } \\
\text { (II) }\end{array}$ & \\
\hline Per $\mathrm{I} \mathrm{cm}^{2}$ area in $\mathrm{mg}$. & & & & & & & \\
\hline a & 7.99 & $7 \cdot 3^{2}$ & 7.66 & $3.9 \mathrm{I}$ & 4.14 & 4.03 & 0.53 \\
\hline $\mathrm{b}$ & 8.44 & 7.61 & 8.03 & $4 \cdot 31$ & 3.76 & 4.04 & 0.50 \\
\hline d & 8.18 & 3.22 & 8.20 & 3.97 & $4 \cdot 37$ & 4.17 & $0.5 \mathrm{I}$ \\
\hline Average & a. 20 & 7.72 & 7.96 & 4.06 & 4.09 & $4.0 \%$ & 0.51 \\
\hline$\%$ on dry weight & & & & & & & \\
\hline a & 337 & 322 & $33^{\circ}$ & 196 & 187 & 192 & 0.58 \\
\hline $\mathrm{b}$ & 30 & 344 & 362 & 192 & 174 & $1 \delta_{3}$ & 0.51 \\
\hline $\mathrm{d}$ & 369 & 355 & $3^{62}$ & 166 & 189 & I'so & $0.5^{2}$ \\
\hline Average & $3^{62}$ & 340 & 351 & Iigi & ז 33 & 183 & 0.54 \\
\hline $\begin{array}{l}\text { Per I cm3 tissute } \\
\text { powder in ing. } \\
\text { a }\end{array}$ & 463 & I030 & 997 & 532 & 593 & $5^{6} 3$ & 0.56 \\
\hline$b$ & III 4 & 1160 & 1137 & $57^{8}$ & 54 & 563 & 0.50 \\
\hline d & 1074 & 1151 & 1113 & 533 & 596 & 566 & 0.51 \\
\hline Average & 1050 & $\mathrm{III}_{4}$ & 1032 & 540 & 5ćo & 564 & 0.52 \\
\hline
\end{tabular}

The experiment were carried out twice and the results agrced in general to two cases. The three kinds of results obtained by the three different methods of indication also showed considerable agreement, the ratios between the values for the stage of permanent wilting and those for the stage of full turgidity being alik for each case. The averages of the values in question were namely $0.5 \mathrm{I}, 0.54$ and 0.52 respectively. 
The values for the water content found in the materials cultivated with different kinds of soil showed little variation, but there was a tendency for the value for the plant cultivated in the soil with higher water holding capacity to be somewhat larger than the others. Therefore we may presume, that this tendency would be more marked, if the soils used for this experiment were more highly different from cach other in their water holding capacity. In truth the water holding capacity of the soils were in this case varied less than in the case of experiments 2. and 4., where the tendency in question cane to light more clearly.

\section{Mimosat}

Ainnosa pudica plants, which were cultivated from seeds in pots filled with the soil b, were used for experiment. The cetermination of the foliar water content for the time of full turgidity was made two hours after the watering the pots. The second determination was done at the critical point of wilting, where all leaves of the plants used lust just their reactivity, even for the strong mechanical stimulations because of the insufficiency of the turgidity in the pulvinus (9). As the laf of this plant is a compound one composed of many small leaflets, the determination of the water content in the leafblade itself could not be undcrtaken. The leaves used for experiment were picked from their insertion point at the stem.

The experiment were repeated five times with five different individuals, five leaves being gathered for each experiment. The values of the water content were given in the percentage on the basis of the dry weight. For this material the area method could not be applied. As

Tals. 10. Water content of the leaves of Mimosit, cultivated in soil b, at the time of full turgidity and of critical wilting.

\begin{tabular}{|c|c|c|c|c|c|c|c|}
\hline \multirow[b]{2}{*}{ Number of malcrial } & \multicolumn{4}{|c|}{$\%$ on dry weight } & & & \multirow{2}{*}{$\begin{array}{l}\text { per } 1 \mathrm{~cm}^{3} \\
\text { tissue } \\
\text { powder } \\
\text { in mg. }\end{array}$} \\
\hline & $\mathbf{I}$ & $=$ & 3 & 4 & 5 & Average & \\
\hline Values at full turgidity (1) & 212.0 & 212,1 & 210.2 & 203.8 & $214 \%$ & 210.6 & I I $4 \mathrm{I}$ \\
\hline Values at critical wilting(II) & 109.1 & 110.7 & 103.6 & 117.2 & III.2 & 111.4 & 603 \\
\hline Ratio (II/I) & 0.51 & 0.52 & 0.52 & 0.58 & 0.52 & 0.53 & 0.53 \\
\hline
\end{tabular}


the meterial gathered from each plant was too scinty for the powier method, all materials used for the five experiments were used together at once for this purpose, and the values of the water content per $1 \mathrm{~cm}^{j}$ tissue powder were calculated from the total sum of values found from total materials (Tab. Io)

According to the results on the basis of the dry weight, the ratio of the values found at the two stages of plants were $0.51-0.58$, the average being 053 . The ratio found by the powcer method wis also 053

\section{Himosa}

In this series of expcriments Mimosa pudica plants, which were raised from seeds and cultivated in four pots with different kinds of soil a, b, $c$ and $d$, were employed. The foliar water content was determined in the same way as in experiment 7 . But in this case, after several leaves were picked from each material at the state of full turgidity for the first test, their branches were cut off for the purpose of hastening the wilting process. When the leaves on the branches cut off reached the critical point of wilting, several of them were picked for the second test.

According to the results obtained in this experiment (l'ab. I1), no definite relation between the foliar water content of plants and the water holding capacity of soils used for cultivation was to be seen. But the

Tab. I1. Water content of the leaves of Whocsid at the time of full turgidity and at the point, at which the leaves on branches cut of are reached the critical state of wilting.

\begin{tabular}{|c|c|c|c|c|c|c|}
\hline \multirow{2}{*}{$\begin{array}{l}\text { Number of } \\
\text { culture } \\
\text { soils }\end{array}$} & \multicolumn{3}{|c|}{$\%$ on dry weight at the time of } & \multicolumn{3}{|c|}{ per $1 \mathrm{~cm}^{3}$ lissta powder at the time of } \\
\hline & $\begin{array}{c}\text { full } \\
\text { turgidity }(I)\end{array}$ & $\begin{array}{c}\text { critical } \\
\text { wilting :II }\end{array}$ & $\begin{array}{l}\text { Ration } \\
\{\mathrm{II} / \mathrm{I}\}\end{array}$ & $\begin{array}{c}\text { full } \\
\text { turgidity }(I)\end{array}$ & $\begin{array}{c}\text { critical } \\
\text { wiltung (II }\end{array}$ & $\begin{array}{l}\text { Ratio } \\
\text { (II/I) }\end{array}$ \\
\hline a & 251 & 113 & 0.45 & 1172 & 530 & 0.75 \\
\hline b & 235 & 97 & $0.4 I$ & 1193 & 393 & $0.3,3$ \\
\hline $\mathrm{c}$ & 292 & I I I & 0.38 & I39I & 466 & 0.34 \\
\hline d & 247 & $\mathrm{II}_{4}$ & 0.46 & 1247 & $45^{1}$ & 0.36 \\
\hline Average & 256 & 109 & 0.43 & 1252 & 460 & 0.37 \\
\hline
\end{tabular}


the degree of water lost at the critical point of wilting was fairly alike in each material. The ratios between the water content of two test periods were namely $0.38-0.45$ with the average value of 0.43 , when the values were found by the dry weight method; and the values found by the powder method were $0.33-0.45$, the average being 0.37 .

Thus the value of ratios in question was found somewhat smaller in this case than in the case of the previous experiment. This difference was caused partly by the too high values for the first test and partly too low values for the second test in this case. Of course there must be several causes relating to this difference, but the principal one would seem to be the difference of the testing method.

\section{DISCUSSION}

The wilting of plants is, as is known, a general symptom cf water deficioncy in the tissues. It must be therefor: a matter beyond question, that the water content of leaves decreases progressively during the process of wilting. But the phenomenon of wilting is a chain of several stages of water deficiency in tissues, which correspond to the physiological states of plants, as the incipient drying ( 14 ), the temporary wilting, the permanent wilting $(3,4)$ etc. If a given state of wilting is nothing more than a symptom of a definite state of the water deficit in tissues of a plant, there nust be a definite water content of tissues corresponding to this state of wilting However, to determine this cefinite water content experimentally is very difficult, unless we may catch exactly a critical point in the progressive phase of wilting. The point of so-called permanent wilting in the sense of Brigas and SHANTz $(3,4)$ or the critical point of wilting of Amosa pudica in the sense of Kôketsu (9) is the only critical stage of wilting, that has received attention in the literature (22). Another critical point of wilting, which we may point out, if not so exactly, is the point of the beginning of visible wilting phenomenon in the leaf. A plant must contain definite amount of water in the leaf tissue at these two critical points of wilting. Caldwer.'s work (5) was based on this idea and he has proved it experimentally. Our results of experiment on Coleus (Fxp. 1.) testified further to his conclusion.

The conclusion, that a plant has a definite water content of leaves at a definite stage of wilting, does not mean, however, that this definite water content is specific for a given plant. The results of the experi- 
ments 2. and 4. on Glycine Soja cultivated in different soils showed, that a given plant contained different amount of water in the tissue of leaves at a given critical stage of wilting, when it is cultivated under different soil conditions. This relation is seen most clearly at the point of permanent wilting. The sane fact is, though somewhat less markedly, derived from the experiments on Coleus cultivated in soils with different water holding capacity (lixp 3). The occurence of the different values of water content in question scems thercfore to be relate at least partly to the difference of the water relation in soils (see 15). Though this relation was not directly brought out in our experiment, it was shown inclirectly by the values of water holding capacity or the water retaining power of the soils used. If therefore we use for experiment soils with less variation in water relation, the fact above mentioned will come less marked. This must be the reason, why we could not find the remarkable difference in experiments 5,6 and 8 .

On the other hand, there is an intcresting fact to be found. In Glycine plants (Exp. 2, 4 and 6), we see, that the water content at the stage of permanent wilting is the larger, as the water holding capacity of the soil used is higher. On the contrary, the results found in Coleus (Exp. 3 and 5) are vice versa. The reason of this phenomenon is not casily analysable. But we assume, that this phenomenon has some relation to the difference of the xerophytism of plants. If we assume, that a mesophytic plant such as Coleus has small power to derive water from soils, while a semi xerophytic plant such as Glycine has larger power, then a plant such as Coleus will fall into the critical state of wilting and will contain less moisture in the leaves, when it is cultivated in a soil with higher water holiing capacity but with higher resistance against the water depriving power, the circumstances for a plant such as Glycine being reversed. Another point of view in this connection is, that a xerophitic plant has a higher power of adaptation for a soil with higher resistance against the water depriving power and is adapted to reserve water in tissues. However the state of things is complicated, if we consider the water content of leaves at the critical point of wilting of different plants. As it is shown in the tables, the watcr content per unit area of leaves is much higher in the leaves of Coleus than in the leaves of soy bean plants. Thus the water content at the critical point of wilting may be higher in the mesophytic plants than in the semi xerophytic plants. However this relation may not apply the succulent plants. 
If the water content of leaves decreases lineally during the process of wilting, so the day value of the water content of leaves at a given stage of wilting will be larger than the value for the following night, thus the day-night ratio coming larger than the unity. This relation night occur, when the desiccating power of air conditions will be relatively high. However, if a given plant loses its tissue moisture relatively slowly, the foliar water content in the day time may be smaller than that of the following night, as is the case in the healthy leaves (14). As is known (I, II), the transpiring power of healthy or wilted leaves shows generally a larger value in the day time than at night. In other words, the water loss from a leaf is smaller at night. If the water supply to a leaf from the stem may overcome the water loss at night, so the water content of a leaf at night will become larger than that in the previous day tine. In this case, the day-night ratio of the water content must be smaller than unity. But the value of this ratio will theoretically approach unity, the more the wilting process of a plant proceeds, until the water supply can no longer cover the water loss.

Thus we may consider two different instances as to the variation in the day-night ratio of water content of leaves. The results obtained from the experiment 1 , on two varieties of Coleus might represent this two probable instances, though there may be other reasons for this state of things. In the case of the variegated variety, we see a regularized march of the day-night fluctuation of the foliar water content. The fluctuation bccones however smaller and smaller, until the plant falls into the state of permanent wilting, the fluctuation at the next stage of wilting becoming once more somewhat larger. This relation is shown clearly by the variation of the day-night ratio for different stages of wilting. This fact is remarkable, if we reflect upon a similar fact found in the march of daily variation of transpiring power of a wilting leaf. As it was pointed out by BAKkE (1) and KôKE'su (II), the daily variation of the transpiring power of a wilting leaf, which was determined by means of hygrometric paper, becomes smaller and smaller, as the plant becomes more wilted, until the plant falls into the state of permanent wilting.

On the other hand there is found another point of interest. The ratio between the water content at the critical point of wilting and that at the point of full turgidity of leaves seems to have a deep meaning in itsself. Though the values of this ratio is not constant for a plant, but may be affected by the culture conditions, it seems however charac- 
teristic for a plant. Thus the values found in the two clifferent series of experiment on Glycine, which were based on the area method, (Exp 2. and 4.), were $0.6 \mathrm{I}$ and 0.59 , the values being given in the average from the values found in the plants cultivated in different soils. This ratio found for the two different varieties of Coleus in the experiment $\mathbf{I}$. were 0.91 and 0.88 respectively, while the value obtained in another variety of this plant (Exp. 5.) was also 0.91.

The values of this ratio seems therefore to be def nite for a plant, if a plant is cultivated under similar conditions Under differcnt culture conditions the values may, however, very not a little. The v.lues found in the five clifferent individuals of Glycine fluctuated between $0.5 \mathrm{I}-074$ with the average 0.61 in experinent 2 . and between $0.51-0.73$ with the average 059 in experiment 4, while the values found in Colcus cultivated in four four different soils gave a fluctuation between 0.89-0.94 with the average $09 \mathrm{I}$. In the case of Glycine the fluctuation was therefore very marked. This fact is without question correlated to the larger difference of the nature of the soil used for this plant. Roughly speaking, the liigher the water holding capacity of the soils used, the larger are the values in question found in this case. There is, thercforc, a parallelism between the values of the ratio and the values of the water content of leaves at the critical point of wilting.

The values in question for Gilycine, which were used for experiment 6 , were found to fluctuate between $0.50-0.53$, the average value being $0.5 \mathrm{I}$. The reason why the values found in this case are relatively low, is probably caused principally by the fact, that the nature of material was different and the plants were cultivated in the soils with relatively low values of water holding capacity.

For the consideration of the water content of leaves the values obtained by the area method were adopted principally, because this method of inclication was considered as theoretically the most reasonable method for our case. But in such a plant as Mimosa it is nearly impossible to employ this method for the determination of foliar water content. To consider the relation in question by the values obtained by the dry weight method and the powder method, it was found in the experiment 7 . of this plant, that the ratio between the values for the water contents at the criticial point of wilting and of full turgidity is 0.53 , the values obtained by the two different methods being the same. The values for Glycine which were found in the experiment 6 . by these two methods, were 0.54 and 0.52 respectively, while the value obtained 
by the area method was $0.5 \bar{i}$ as alreaciy mentioned. That is to say, the values obtained by the dry weight or the powier method brought similar results, as in the case of area method.

In comparing the values of ratio obtained in Mimosa and cilycine, we see at a glance, that the values ate very similar to each other. But we nust bear in mind in this case, that the methods of determination of the critical point of wilting were different, BRuggs and SHANT\%' method for the latter and Koketse's method for the former being used. Moreover the manner of gathering materials for experiment was different. Ilowever it may be assumed, at least, that the values in question for these two plants will be neal to each other. In experiment 8., where the critical point of wilting was determined in the leaves on the detached branches of Mimosa, the values in question came to light somewhat lower than in the case of experinent 7 ., where the rooted plants were employed for experiment. The reason of this difference may be caused, as is atrcady discussed, principally by the difference of testing methods.

Thus the crilical foliar water content of a plant may come to light in the cifferent values, according to the difference not only of the culture conditions but also of the testing method. Therefore, if we hope to compare the water relations of different plants, we must test with the same method and with materials cultured under the same conditions. On the other hand we must employ the reasonable methods of cietermination of water content for a given case In our case it is beyond question, that the fresh weight method of determination is least applicable. As regards the dry weight method, it will theoretically bring reasonable results in some limited cases, where the content of the dry matter in leaves is but slightly variable. But in such a case, where the dry substance varies not a little luring the experiment, this method also is not applicable. Thus in many cases in our experiment the results obtaincd by this method appeared as in point of fuct less reasonable, than in the case of area method. Therefore our consideration on the water relation in question was based principally on the results obtained by the area method. When this method was not applicable, we were obliged to depend upon other methods. KôkErst's powder method $(8,10)$ was introduced here as a theoretically reasonable method and proved an applicable method in this case.

I ooking back upon the water relation of plants as related to the wilting once more, we may derive a point of interest from the data obtained in our experiments on different plants The water residue in 
the leaf at the critical point of wilting is very different in the different plants. This critical water resiclue given by the ratio to the water content at the full turgidity is very high in Coleus in comparing with that of Glycine plants, while this value for $M$ m mosa is rather similar to that of Glycine. In other words Coleus plants lose the relatively small amount of their foliar moisture, before they fall into the critical state of wilting. The degree of the water loss seems in this connection to be an index showing the degree of the resistance of a plant to wilting. The higher is the ratio in cuestion, the less xerophytic might a plant be This conclusion agrees closely with the Maximow's words: "Xerophytes can enclure without injury a greater loss of water than mesophytes" (20)

\section{SUMMARY}

I. The variation of the foliar water content as related to the wilting of plants was studied by determining the water content at the critical stages of wilting of leaves, Coleus Blumei, Glycine Soja and Mimosa pudica being used as the materials for experiments.

2. As the index to show the water content of lcaves, not only its percentagc values on the basis of the fresh and dry weight also the amount contained in the unit area of the leaf were determined. The content per unit volume of the tissue powder was also attributively determined. Ilowever, it was proved, that the area method was prefuable to the percentage methods. The consideration of results was made therefore principally on the values obtained by this method. But in the case of Minosa, where this method was impracticable, the values obtained by the dry weight method was applied. The powcler method was also proved to be a good applicable one.

3. The water content of leaves of a plant seemed to be very alike at a given critical stage of wilting, for instances at the beginning of wilting or at the point of so-called permanent wilting of a plant. But this value was affected not a little by the culture conditions. The higher the water holding capacity of culture soils, the larger was the critical water content of leaves of Glycine, while the results found in Coleus were the opposite. This relation was assumed by the writer to have some bearing on the xerophytic nature of plants.

4 The water content of leaves at the critical wilting point of different plants was proved very different to each other. The ratio of 
this critical water content to the content at the stage of full turgidity was also very different one from the other. The value of this ratio was found much higher in Coleus than in the other two materials, while the values for these latter two were near to each other.

5. The ratio in question seemed moreover to be specific to a given plant, and to show the clegree of the resisting power of a plant to wilting. The value of this ratio might be, therefore, an index to compare the degree of the xerophytism of plants, the more xerophytic being a plant, the lower is the value.

\section{LI'TERATURE.}

1) Bakke, A. L. (Iy 15$)$, The index of foliar transpiring power as an indicator of permanent wilting in plants. Bot. Gaz. 60:314-31y.

2) BRIGGS, I, J. and Ll. L. SHANTZ (1911), A wax scal method for detcrmining the lower limit of available soil moisture. Bot. (aaz. 51:210-219.

3) - - and - - (1912), The wilting coefficient and its indirect determination. Iot. Ga.. $53: 20-37$,

4) _-.._ and - ( 1912 ), The relative wilting coefficient for different plants. Bot. Gaz. $53: 229-235$.

5) Calmwelt., J. S. (1913), The relation of environmental conditions to the phenomenon of permanent wilting in plants. J'hysiol. Research $1: 1-50$.

6) IIIRciakt, E. W. (1919), Soils. New York.

7) KNigire, R. C. (1922), Further observation on the transpiration, stomata, leaf water content, and wilting of plants, Ann. 1\%ot. $3^{6: 361-384}$.

8) KôkEIsU, R. (1924), Ueber den gehalt an Trockensulstanz und Aschc in einem bestimmten Volumen Gewebepulver als Indizium für den Gehalt des Iflanzenkörpurs an denselben Konstituenten. Jour. Dept. Agr. Kyushu Imp. liniv. 1:151-162,

9) - - , (1925), Ueber die Anwendung der Afimosa fudia als Index-pflanze zur Bestimmung des Wasserhaltungsvermögens verschiedener Bodenarton in Beziehung auf das Welken der Pflanzen. Bot. Ming. (Tokyo), 39: i $52-158$.

I0) - - , (1925), Ueber die Irauchbar- und Zweckmässigkeit der ,P'ulvermethode“ für die Jestinumung des Wassergchaltes im I'flanzenkörper. Bot. Mag ('Tokyo) 39: 16y-175.

11) - - , $(1926\rangle$, Variation of the transpiring power of leaves as related to the witing of plants. Jour, Dept. Agr, I:24 I-260.

12) - - , (1927), Ueber die Erregbarkeit der Jitallgclenke der Mimost fautica. Bot. Mag. (Tokyo) $41: 78-99$.

13) - - and S. YastDA (I9 7 ). Leber den Fffekt der Anwendung der "J'uvermethode“ für die Bestimmung des Stoffgrehaltes im Pflanzenkörper. Bult. Sci Fakul. Terkul. Kjı̂ิu Imp. Univ. 2:200-208.

14) Livingston, B. F. and W. H. Brows (1912), Relation of the daily march of transpira tion to variations in the water content of foliage leaves. Bot. Gaz. $53: 300-330$.

15) - - and R. KokErsu (Ig20), The water supplying power of the soil as related to wilting of plants. Soil Sci. 9:469-485. 
I6) I.I.OYD, F. F. (I9I2), The relalion of transpiration and stomatal movement to the watcr content of the leaves in Finguicrio sflenders. Plant World 15:1-14.

I7) - - , ( $\left(\mathrm{t}_{1} \mathrm{1}_{3}\right)$, Leaf water and stomatal movement in Gossifium and a method of desert visual obscrvation of strmata in situ. Jul. Torrey Pot. Club 40:1-25.

18) Maxidow, N. A. (1923), Physiologisch-ökologische Untersuchungen uiber die Dïrreresistenz. der Xerophyten. Jahrb. wiss. Bot. 6z:120̈-144.

19) _-_ and 'T. A. KRAsNesstisky-MaXimow (19z4), Wilting of plants in its connection with drought resistance. Jour. Ecrl. 12:95-110.

20) - - , (19z6), The physiological hasis of drought resistance of plants. Bull. appl. Bot. and Plant-Breed, (Leningrad) I926:393-407.

21) Simve J. W. and B. E. I Iviscston (19I4), The relation of atmospheric evaporating power to soil moisture content at permanent wilting of plants. P'lant World 17:8x-121.

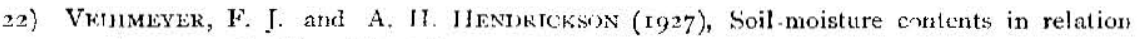
to plant growth. Plant I'hysiol. 2:71-82 